\title{
What Marxist Tax Policies Actually Look Like
}

\author{
David Ireland \\ Independent Researcher \\ ireland2007@btinternet.com
}

\begin{abstract}
'Marx on tax' as an effective antidote to inequality is an overlooked theme within his own output, but also for our own time. Marx theorising on tax is seen even by preeminent Marxists as an empty box, but Marx and Engels in fact had plenty to say about tax. Their coverage embraces progressive taxes, both on capital and income, a strong preference for direct over indirect taxation, inheritance tax, land-value tax, taxes on financial transactions, and state finances around the world. Tax also provides the battleground for a rare sight of Marx as campaigning activist, in 1848, matched in the same period by close ally Wilhelm Wolff. The tax policies of Marx and Engels have been neglected because they are primarily to be found in their journalism and letters. They are no anachronistic curiosity but perfectly applicable to the income and wealth inequalities of our own era.
\end{abstract}

\section{Keywords}

tax theorising - inequality - activism - Marxist disinterest - journalism

\section{Introduction}

It is a moot point whether the UK Labour Party is as Marxist as both its supporters ('Marxism is everywhere in modern Labour') ${ }^{1}$ and detractors ('the possibility of a Marxist in No. 10'), ${ }^{2}$ to the left and the right, contend. What seems far less questionable is that the pressures on the UK economy already apparent (slowing GDP growth, exhausted austerity measures, rising spending

1 Mason 2017.

2 Daily Mail 2017.

(C) DAVID IRELAND, 2019 | DOI:10.1163/1569206X-00001543

This is an open access article distributed under the terms of the CC-BY-NC-ND license at the time of publication. 
demands), even before the full negative economic consequences of Brexit manifest themselves, will make raising taxes in the UK an unavoidable imperative. For a Labour government in waiting, or in power, and for those opposed to Labour, what Marxist, or perhaps 'Marxist', tax policies might actually look like is very much back on the political agenda.

Fleshing out a Marxist tax programme is, however, problematic, if one's first recourse is to the pre-eminent Marxist economists. David Harvey, in his latest book on Capital, claims of Karl Marx that taxation 'remains an empty box in his theorising' ${ }^{3}$ (which he explains by reminding us of the stillborn project on the state outlined in the Grundrisse). ${ }^{4}$ Harvey is by no means alone. Maurice Dobb and Paul Sweezy barely connect Marx with tax, while Ernest Mandel devotes only ten pages of his 8oo-page primer, The Formation of the Economic Thought of Karl Marx, to the question of taxation. Marxist historians - E.P. Thompson, Eric Hobsbawm, George Rudé and Karl Obermann - to an extent step into the breach, but with essentially bottom-up (and nineteenth-century) socialhistory references to the then implications of tax. Selectively, state finances have certainly been discussed, by James O'Connor, Michael Krätke ${ }^{5}$ - something of a lone voice for highlighting the importance of the tax dimension for Marx - and Ian Gough, but the fact that Duncan Foley can offer (in a 16-page essay) State Expenditure from a Marxist Perspective, but one not involving tax, rather epitomises the general Marxian disengagement with the theme of tax.

In fact, Marx and, in this thematic context, Friedrich Engels and Wilhelm Wolff (to whom Marx dedicates Volume One of Capital) ${ }^{6}$ had a great deal to say about tax. Marx himself acknowledged the primacy of tax, both as a burden on the poor ('what reasoning citizen would not have referred the starving people to taxes ... as the source of its misery?'), ${ }^{7}$ and as a catalyst for political change ('The initial causes for the overthrow of kings ... have always been questions of taxation'). ${ }^{8}$ Marx and Engels, from the early 1840 s right up until - in Engels's case - the early 189os, make a string of prescriptive observations very much of contemporary resonance. These cover progressive taxes, both on capital and

3 Harvey 2017, p. 15.

4 Harvey does not spell out the project here, but it was to include taxes, national debt and public credit; Marx 1986a, p. 45. See also Krätke 2009, pp. 119-21.

5 Krätke (also an authority on Marx as a financial journalist, see Krätke 2006) covers public finances both via the involvement of Marx, and also of later non-Marxists (for instance, Goldscheid and Schumpeter).

6 'My unforgettable friend ... Intrepid, Faithful, Noble Protagonist of the Proletariat'; Marx 1996, p. 5. Engels described Wolff in 1876 as 'our most faithful friend'; Engels 1989, p. 171.

7 Marx 1976, p. 328.

8 Marx 1977a, p. 477. See Sperber 2005, p. 50: 'In 1848 ... questions of taxation would prove to be an extraordinarily powerful force for political mass mobilisation'. 
income, a strong preference for direct over indirect taxation, inheritance tax, land-value tax, taxes on financial transactions, and state finances around the world and their drivers. There is even some tacit endorsement of tax evasion, both personal (by Marx) and corporate (by Engels).

Marx and Wolff also ran activist campaigns around tax in 1848-9 contrasting the lives of peasants and labourers with those of the $1 \%$-ers of their day - via the Neue Rheinische Zeitung (NRZ), the newspaper for which Marx, Engels and Wolff were the driving forces. Marx's personal involvement in this campaigning belies his subsequent image as a London recluse at his British Museum library desk.

This article sets out to fill the 'empty box' that is the current perception of 'Marx on tax'. It examines the tax theorising of Marx and Engels - by establishing first its significant and practical contribution to today's inequality debate, and then by analysing its key components. It then considers the campaigning on tax by Marx (and the rare activism on his part), Engels and Wolff; why other Marxists have not engaged with tax; and what tax avenues Marxians of today could be exploring.

\section{Tax and Inequality}

While Marx and Engels present no overarching theory of inequality they do frequently discuss income inequality, and tax inequality - but with a striking contradistinction. Whereas Marx and Engels clearly perceive income inequality as irremediably inevitable under capitalism, reducing tax inequality, in contrast, is regarded as perfectly achievable while capitalism persists.

Marx makes the case for the legitimacy of income inequality both in the Grundrisse ('the wages being paid are economically just, i.e. determined by the general laws of political economy') ${ }^{9}$ and in the Critique of the Gotha Programme ('the only "fair" distribution on the basis of the present-day mode of production'). ${ }^{10}$ Engels argues similarly, first in Anti-Dühring, where 'the manner in which wealth is distributed' is dependent on the prevailing structure of production, ${ }^{11}$ and then in his 1885 Preface to the Poverty of Philosophy ('the greatest part of the product does not belong to the workers who have produced it. If we now say: that is unjust, that ought not to be so, then that has nothing

$9 \quad$ Marx 1986a, p. 354.

$10 \quad$ Marx 1989, p. 84; see also Hollander 2004, pp. 6-9.

11 Engels 1987, p. 254; Hollander 2004, p. 14. 
immediately to do with economics'). ${ }^{12}$ The inequality - prevailing production nexus is encapsulated in Lawyers' Socialism, the 1887 rebuttal by Engels (with help from Karl Kautsky) of Austrian lawyer Anton Menger, 'the demand for equality, just like that for the full fruits of one's labour, became entangled in insoluble contradictions ... leaving the heart of the matter, the transformation of the mode of production, more or less untouched.' ${ }^{13}$

Marx and Engels seem no less definite, for the most part, that tax inequality, in contrast, can be addressed by tax reforms that do not require the advent of communism. This latter notion needs to be caveated by their writings in the 1840 s, where tax proposals do go hand in hand with communism, but the progressive income tax, for instance, called for in that decade becomes subsequently, right up to the 189os, a policy preference detached from communism, featuring in discussions of the English budget, the Gotha Programme and the 1891 draft programme of the German Social Democrats. Direct taxes over indirect, and reforms of inheritance tax, similarly, are seen as desirable, within a capitalist environment. There are, it needs to be acknowledged, other policies - the progressive tax on capital and land-value tax - which are presented hand-in-hand with communism, but even here, they are of sufficient interest both in their historical context, and for the contribution they make to the inequality debate today, to be well worth discussing.

\section{Tax Policies of Marx and Engels}

The tax landscape of Marx and Engels is clearly different to our own - thus in 1849, indirect taxes accounted for $40 \%$ of the Prussian Royal Finance Ministry total tax take, and direct taxes, only $29 \%,{ }^{14}$ whereas today in the UK or Germany, indirect taxes are in the minority, with direct taxes generating around two-thirds of the total take. It is notable, however, that the tax commentary of Marx and Engels is by no means an anachronistic curiosity, but, rather, very much covers the tax issues that preoccupy us today.

Engels addressed two meetings in Elberfeld, in the Rhineland, in February 1845 on the subject of communism. His letter on Elberfeld to Marx on 23 February 1845 is perhaps needlessly facetious ('You have no idea how favourable the soil is here. The most stupid, indolent, philistine people ... are almost beginning to rave about communism'). The bourgeois gatherings were also

\footnotetext{
12 Engels 1990a, pp. 281-2.

13 Engels 1990a, p. 599.

14 Dieterici 1853 , pp. 4, 29.
} 
distinctive for 'only the proletariat being excluded. ${ }^{15}$ The opening Elberfeld speech, on 8 February, however, marks the first noteworthy intervention in tax policy by either man. ${ }^{16}$

Engels sets the tone with an observation redolent of current $1 \%$-er commentary - 'there is general lamentation about the fact that property is being accumulated daily in fewer hands and that ... the great majority of the nation is becoming more and more impoverished. Thus there arises the glaring contradiction between a few rich people on the one hand, and many poor on the other'.17 He then proposes two practical measures by which communist theory could be 'translated into reality' (the first very much with a current relevance) - 'the general education of all children without exception at the expense of the state - an education which is equal', and 'a complete reorganisation of Poor Relief'. ${ }^{18}$ He goes on:

Both these measures require money. In order to raise it and at the same time replace all the present, unjustly distributed taxes, the present reform plan proposes a general, progressive tax on capital, ${ }^{19}$ at a rate increasing with the size of the capital. In this way, the burden of public administration would be shared by everyone according to his ability and would no longer fall mainly on the shoulders of those least able to bear it, as has hitherto been the case in all countries. For the principle of taxation is, after all, a purely communist one. ${ }^{20}$

Nearly 170 years later, Thomas Piketty's 'ideal policy' for 'avoiding an endless inegalitarian spiral and regaining control over the dynamics of accumulation' is precisely a 'progressive global tax on capital' (and one that 'can be quite steeply progressive on very large fortunes'). ${ }^{21}$

Engels's proposition here of a tax on capital has a merit, too, in its clarity of purpose. While the line taken by the Marx circle on tax is in general remarkably consistent, across some 50 years - importantly, notwithstanding its

\footnotetext{
15 Engels 1982, pp. 23, 22.

16 On their own account; tax-related commentary on the work of others occurs as early as Engels's 1839 approving comments on Jacob Venedey's Preussen und Preussenthum; Engels 1975a, p. 480.

17 Engels 1975b, p. 244.

18 Engels 1975b, pp. 253-4. The education policy becomes the tenth measure of the Manifesto; Marx 1976, p. 505.

19 Engels uses the very precise German word 'Kapitalsteuer' for 'tax on capital'.

$20 \quad$ Engels 1975b, p. 254.

21 Piketty 2014, pp. 471, 532.
} 
piecemeal assembly - there is undoubtedly a caesura in the case of Marx himself in the period 1847-50. Marx at this time decries progressive tax as a 'bourgeois measure. ${ }^{22}$ 'Tax reform is the hobbyhorse of every radical bourgeois ... the reduction of taxes, their more equitable distribution, etc., etc., is a banal bourgeois reform. The abolition of taxes is bourgeois socialism'. ${ }^{23}$ The introduction of income tax, the most prominent form of direct taxation, as a substitute for regressive indirect taxes such as the then Milling \& Slaughter Tax is also viewed as counter-productive - 'capitalists will not and cannot allow their profits to be taxed with impunity'; ${ }^{24}$ wages will be correspondingly reduced.

This line of thinking is perhaps most obviously a political response to the events of 1848, and the conclusion, as Marx spelt out in The Bourgeoisie and the Counter-Revolution (and as Stedman Jones reflects) that 'a purely bourgeois revolution and the establishment of bourgeois rule in the form of a constitutional monarchy is impossible in Germany'.25 Given its limited lifespan, such thinking seems to represent essentially a temporary attack of cognitive dissonance. This, after all, is first very much the same period in which Marx and Wolff are activist tax-campaigners, and in which progressive tax (and other tax reforms) are first being previewed, and then formally proposed in the Manifesto. Subsequently, and over a long timeframe, the supportive remarks on progressive tax per se, on progressive income tax, and on direct taxation in preference to indirect surely cast Marx's critique of tax reform in $1847-50$ as an aberration.

The Manifesto of 1848 , of course, lists 'a heavy progressive or graduated income $\operatorname{tax}^{\prime 26}$ as one of its required measures. Co-author Engels talks in the precursors to the Manifesto of limiting private property in such a way that it gradually prepares the way for its transformation into social property, e.g. by progressive taxation'27 (Draft of a Communist Confession of Faith, 1847) and of the 'limitation of private ownership by means of progressive taxation'28 (Principles of Communism, 1847). The Address of the Central Authority to the League, 'almost certainly written by Karl'29 in March 1850, stipulates: 'If the democrats themselves put forward a moderately progressive taxation, the

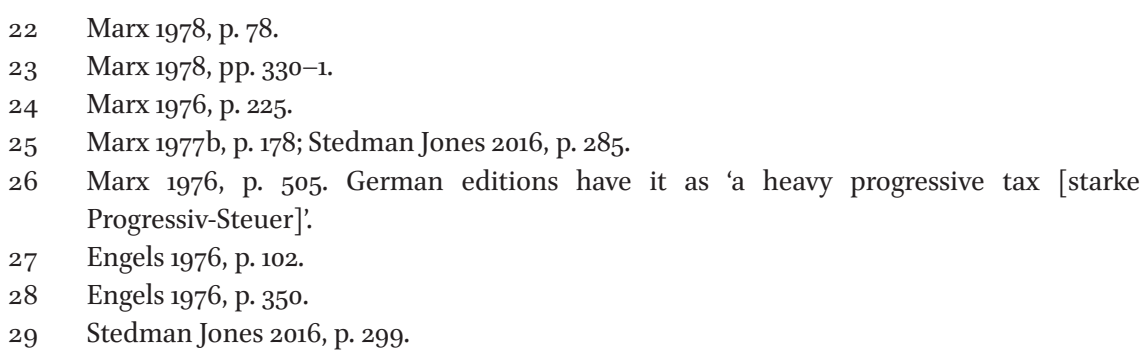


workers must insist on a taxation with rates that rise so steeply that big capital will be ruined by it'.30

Well beyond the $1847^{-50}$ timeframe, there is also no shortage of support for progressive taxation. Writing on the English Budget in 1853, Marx argues 'our notion of taxation would sooner incline to a graduated scale in which the percentage increased with the amount of the income. ${ }^{31}$ In his Critique of the Gotha Programme, in 1875, Marx writes 'the German workers' party demands as the economic basis of the state: a single progressive income tax', ${ }^{\prime 2}$ while Engels's thinking on the 1891 draft programme of the Social-Democratic Party of Germany is reflected in the call for 'progressive ... tax to cover all expenditure of the state, district and community'.33

Today, while the rate at which income tax is levied is frequently challenged, the justification for its existence (accounting, as it does, for $45 \%$ of the current UK tax base, for instance), hardly at all. This was certainly not the situation around the middle of the nineteenth century when Marx and Engels started to formulate their views on direct taxes - most obviously income tax - and indirect taxes. Income tax was first legitimised by war. In the UK, it was introduced in 1799, abolished in 1802, reintroduced a year later and then abandoned in 1816 at the end of the Napoleonic wars before being brought back by Robert Peel in 1842. In Prussia, an income tax existed just briefly from 1812 to 1814, not re-emerging until 1851. As Marx frequently discusses in the 1840 s and 1850 , superseding predominant, regressive and much less visible indirect taxes with direct taxes was very much a live issue.

Marx's overall support for direct taxes to replace indirect ones is clear-cut. Indirect taxes are frequently identified as an evil. The 'popular hatred of the wine tax' in France is explained by Marx because 'it increases in geometrical progression as the wealth of the consumers decreases, an inverted progressive tax.' ${ }^{34}$ In The Poverty of Philosophy, Marx argues that 'in constitutional governments, impositions are more generally laid upon consumption. Everyone is taxed according to his expenditure. ${ }^{35}$ The seesaw relationship between funding through direct or indirect taxes is spelt out. On the New English Budget, writing in 1857, Marx writes: 'Decrease in the income-tax to be counterbalanced by the increase in the duties on tea and sugar - the latter being

\footnotetext{
$30 \quad$ Marx 1978, p. 286.

31 Marx 1979, p. 64.

$32 \quad$ Marx 1989, p. 96.

33 Engels 199ob, p. 230.

34 Marx 1978, p. 119.

35 Marx's explanatory note on James Steuart's Recherche des principes de l'économie; Marx 1976, p. 196.
} 
common necessaries with the British people - means evidently diminishing the taxes on the rich by augmenting the taxes on the poor.' ${ }^{36}$ In The Class Struggles in France (perversely, where he is also anti-reformist), Marx criticises the 'retention of the wine tax! Abandonment of Passy's income tax'. ${ }^{37}$ Against this outline of the impact of direct as opposed to indirect taxation, Marx and Engels come up with a clear policy preference. In response to Lassalle's 1863 speech on indirect taxation, Marx remarks, 'indirect taxation, is, in true schoolboy fashion, seen as "bourgeois taxation", and so indeed it was "in the Middle Ages", but not today'.38 Engels, meanwhile, writes to Eduard Bernstein in 1882, 'The wholesale condemnation of indirect taxation has been mooted by us as far back as 1849 and ' 50 , and that's where Lassalle got it from.' ${ }^{39}$ As well as these more outspoken observations on the relative merits of the two forms of taxation, 'Direct and Indirect Taxation' was an agenda item put forward for the 1866 International Workingmen's Association (IWMA) conference. ${ }^{40}$ Engels's comments on the 1891 draft programme of the Social-Democratic Party of Germany included a call for the 'abolition of all indirect state and local taxes, duties, etc.'41

Restrictions on inheritance are one of the founding principles of the communism put forward by Engels and Marx in the late 1840s, as a way of transforming private property into social property, but the scale of restriction varies, and the restriction framing is not always tax-based. In his June 1847 Draft of a Communist Confession of Faith, Engels calls for limitation of the right of inheritance in favour of the state', and in the October 1847 Principles of Communism, for 'high inheritance taxes, abolition of inheritance by collateral lines (brothers, nephews, etc.)'. The Manifesto hardens the proposal into 'abolition of all right of inheritance', although in the $185^{0}$ The Class Struggles in France, 'socialism proper' is once more seeking only limitations on inheritance., ${ }^{42}$ In his 1869 pamphlet and later speech for the General Council on the right of inheritance, Marx returns to the notion of 'social change superseding private property' but he now believes that 'by abolishing the right to inheritance, everything would be disturbed and nothing got'. Instead, he proposes solely increasing inheritance tax, to boost public funds: 'we had legacy duties already, all we had to do was to increase them and make them progressive ... leaving the smaller

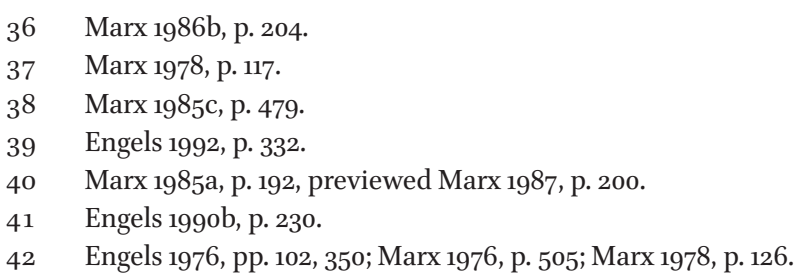


amounts, $£_{50}$ for instance, free ${ }^{433}$ (this is precisely like a modern inheritancetax nil rate band).

In one of the most egregiously misplaced associations of the UK Labour party with Marxism, Conservative UK Chancellor Philip Hammond argued that Labour's (tentative) support for a land-value tax (LVT) in its 2017 election manifesto would be 'attacking land on Marxist principles' ${ }^{44}$ In fact, both Marx (and Engels) make very plain their opposition to LVT, a tax first propounded by Adam Smith and David Ricardo, but most closely associated with American political economist Henry George, in Progress and Poverty, first published in 1879 but discussed by Marx in two letters in June 1881 (to John Swinton and Friedrich Sorge).

This opposition to LVT (an annual tax on the unimproved value of land) might seem perplexing given that the first of the 10 measures outlined in the Manifesto is 'expropriation of property in land and application of all rents of land to public purposes'.45 But Marx disowns this measure in the Sorge letter 'we ourselves adopted the appropriation of rent by the State amongst many other transitional measures which, as is likewise indicated in the Manifesto, are and cannot but be contradictory in themselves.' 46

In Progress and Poverty, George discusses the characteristics of 'the best tax', the first of which is 'that it bear as lightly as possibly upon production. ${ }^{47}$ George is very much true to his word, since in this sphere of production he would have the landowner pay LVT, but otherwise retain ownership of the land.

This, Engels summarises in the 1887 Preface to The Condition of the Working Class in England, is why George's application of LVT is so unsatisfactory:

If Henry George declares land-monopolisation to be the sole cause of poverty and misery, he naturally finds the remedy in the resumption of the land by society at large. Now, the Socialists of the school of Marx, too, demand the resumption, by society, of the land, and not only of the land but of all other means of production likewise. But ... what is to be done with the land?

Modern Socialists, as represented by Marx, demand that it should be held and worked in common and for common account, and the same with all other means of social production, mines, railways, factories, etc.; 
Henry George would confine himself to letting it out to individuals as at present, merely regulating its distribution and applying the rents for public, instead of, as at present, for private purposes. What the Socialists demand, implies a total revolution of the whole system of social production; what Henry George demands, leaves the present mode of social production untouched. ${ }^{48}$

James Tobin proposed what became his eponymous potential tax on currency transactions only in 1972, but the idea of a more generic financial-transactions tax is of far greater longevity. An ad valorem stamp duty on the transfer of shares was introduced in 1808 in the UK, with stamp duty on securities transfers and contract notes coming into effect in Germany in $1881 .{ }^{49}$ In an exchange of letters with Eduard Bernstein in February 1883 on the question of a 'stock exchange tax' [Börsensteuer], Engels says that while he is happy to denounce 'the immorality and rascality of that exchange', he is opposed to a 'stock exchange tax': 'I am against it, 1), because we in general only ask for direct taxes and reject all indirect ones, so that the people know and feel what they're paying for ...50

Marx's planned comprehensive critique of state finances, with sections on taxes and state debt, was largely stillborn, bar in Volume One of Capital when discussing ever-rising national debt and its concomitant funding ('modern fiscality ... contains within itself the germ of automatic progression. Overtaxation is not an incident, but rather a principle'). ${ }^{51}$ Marx did, though, extensively discuss state finances, and, in particular, state budgets. He ranged across budgets in Prussia ('fraudulent') ${ }^{52}$ in the 1840 (also separately compared with the US budget for 1848), France in 1849 and the 1850s, and England in the 1850s (he also covers Austria's bankruptcy and Russian war finances in 1854, and India's taxation in 1858 and financial crisis in 1859, while Engels gives a breakdown of the Burmese tax base in 1858). Some of the budgetary comment is rather mechanically descriptive - thus, the varying rates of English tax on tea and sugar imposed by Gladstone - but a common and more analytical Marx preoccupation is national debt, how it has arisen, and the levers which affect it (such as the increase or reduction of direct and indirect taxes, and their interplay).

While it might be expected, or at any rate hoped, that Marx and Engels always occupied taxation's moral high ground, it is not consistently true.

\footnotetext{
$48 \quad$ Engels 1990a, p. 438.

49 Reichstempelgesetz.

50 Engels 1992, pp. 435, 433 .

$5^{1} \quad$ Marx 1996, p. 744.

$52 \quad$ Marx 1977b, pp. 379-89.
} 
Joseph Hill looked back in 1892 at the self-effacing self-assessment of earlier Prussian Class Tax payers: 'It had been thought that the social pride of the taxpayer would come to the assistance of the assessors, and that he would resent being rated in a lower class than the one to which he actually belonged ... but in general, the Prussian subject, when it came to the question of taxation, did not seem to aspire to a high social position. ${ }^{53}$

Marx, writing in 1848 on The Bill on the Compulsory Loan and its Motivation, seems to share this prevailing attitude. He first quotes Prussian Minister of Finance David Hansemann, 'Not even a summary listing of the individual parts of one's property will be required ... The district commission set up to examine self-assessments will call for appropriate contributions by way of amicable exhortations .... This might be thought quite benign by comparison with the far more onerous personal-reporting regime in force in the UK today, but Marx is first mocking: 'Anybody who is familiar with the economic impossibility of an exact estimate of wealth ... Herr Hansemann does not appear to be afraid that his Spartans will assess themselves too heavily'. Then he rails against the disclosure process imposed on those deemed to have under-assessed their own wealth: 'Whoever refuses to accept without reservation the "assessment" of the officials appointed by the Finance Minister, may, as a penalty, have to reveal all his financial affairs to two bureaucrats and 15 competitors'. He finally trumpets 'it is the duty of every patriot to refuse to contribute a single penny voluntarily to the compulsory loan'. 54

In 1892, Engels in London similarly moans to his brother Hermann in the Rhineland, 'we poor rentiers are made to bleed for 1 . tax on our dividends, mortgage interest, etc., is actually deducted before we receive the money and 2. woe betide us if we have any other sources of income and do not voluntarily notify the tax authority'. Hermann is duly asked to send the necessary paperwork on his brother's German income post-haste - which might cast Friedrich as model citizen - but it transpires earlier that Friedrich's indignation as a persecuted 'poor rentier' is fuelled by an opening observation to Hermann. Friedrich asks, 'I don't know whether your procedure regarding the declaration of incomefor-taxation purposes varies very much from ours, but over here, it is what we have been used to for the past 40 years or more and, between ourselves, I have yet to come across a case in which a firm makes a true declaration of income; as a rule, it is understated by $30 \%, 40 \%, 50 \%$ and more. All this is

53 Hill 1892, p. 211.

54 Marx 1977a, pp. 284-6. 
allowed to pass, for immediately the authorities start making trouble ... there is a general outcry from the mercantile world' 55

While the names of taxes have, of course, changed since the era of Marx and Engels (there is no longer a salt monopoly, worth $9 \%$ of the total Prussian tax take in 1849, while capital gains and corporation tax were not introduced into the UK until 1965, and VAT, until 1973), the principles on which taxes are based and debated have not changed. It is in the area of principles and preferences that the tax policies of Marx and Engels are very much of contemporary relevance. Within our existing tax landscape, their consistent (Marx's aberrant thoughts in $1847-50$ aside) advocacy of progressive taxation, particularly of income, their strong support for direct over indirect taxes, and their urging of higher inheritance tax are all very germane to us today. ${ }^{56}$ In the policy arena, Engels's 1845 promotion of a progressive tax on capital directly foreshadows Piketty. Only property - albeit in the specific context of a Land Value Tax - stands out as an anomaly in the overall Marx/Engels tax canon. Marx and Engels regarded reducing tax inequality otherwise as perfectly achievable under capitalism, but land ownership and its taxation could only be contemplated under communism, or by 'modern Socialists', as Engels put it in 1887 , an issue that has to be addressed in any modern Marxist tax programme, given the importance of property to both inequality and taxation.

\section{Activist Tax-campaigning - Marx, Engels, Wolff and the Neue Rheinische Zeitung}

While the Engels/Marx prescriptive theorising on tax spans nearly 50 years, from 1845 to 1892 their activist tax-campaigning was carried out in and through the short-lived (June 1848-May 1849) Neue Rheinische Zeitung (NRZ). Marx, Engels and Wolff were very much the driving forces of the NRZ. Marx was Editor-in-Chief, publisher, organiser, and, in due course, sole proprietor of the $N R Z$. Engels was 'the specialist on foreign policy issues ... wrote more editorials than anyone else. He and Marx took turns in writing the most important articles'. Wolff 'contributed articles on the agrarian question, on the condition of the peasants and their movement, particularly in Silesia, ${ }^{57}$ but the collation,

$55 \quad$ Engels 2001, p. 353 .

56 The OECD, for instance, in 2018 advocated higher inheritance tax to reduce wealth inequality.

$57 \quad$ Marx 1977a, p. 604. 
working-up and clarification of reports about tax boycotting was also 'in large part Wolff's work.'.58

The geographic backdrop for the tax campaigning is Prussia, accounting in 1850 for half the population of the German state, as it would be constituted in 1871.

Marx's No More Taxes!!! [Keine Steuern Mehr!!!], a prototype ‘Can’t Pay, Won't Pay' campaign, spanned some 30 key $N R Z$ articles, and effectively ran between 11 November and 7 December $1848 .{ }^{59}$ It drew on both civil disobedience orchestrated by Marx, and parliamentary support from the Prussian National Assembly (PNA, whose members first convened in Berlin on 22 May 1848, to draft a constitution, but 'by agreement with the Crown'). ${ }^{60}$ The campaign failed after forcible interventions by the military, legal pressures on Marx that resulted in a state trial on 8 February 1849, and the dissolution of the PNA on 5 December 1848.

Ernst Huber seems quite wrong to suggest that the tax boycott was 'in practice not addressed to the broad masses, but to those obliged to pay tax, and thus, in line with the then prevailing tax laws, to the propertied'.61

Marx in fact especially targeted the rural poor $(72 \%$ of Prussia's population in 1849 being rural) and a particularly unpopular tax, the indirect Milling \& Slaughter Tax [Mahl- und Schlachtsteuer]. Indirect taxes (especially excise duties on consumer staples such as meat, beer, sugar, and also customs tolls) and the (direct) Class Tax [Klassensteuer] levied on adults between 16 and 60 contributed $51 \%$ of the $c .70$ million Thalers Prussian Finance Ministry annual tax take, ${ }^{62}$ the remaining direct taxes such as the Land Tax [Grundsteuer] and a small tax on company profits [Gewerbesteuer] comprising a mere $18 \%$ slice. Nobles, moreover, were exempt from the Land Tax.

The Milling \& Slaughter Tax was levied on such food staples as rye and wheat flour, pork and beef, and was paid by c.2.1m Prussians, or $13 \%$ of the population, ${ }^{63}$ in 101 mainly larger towns (in 1848). There were some exceptions Barmen and Elberfeld, Engels's birth and schooling towns respectively, Krefeld

$5^{8} \quad$ Schmidt 1979, p. 193.

59 Somewhat oddly, Keine Steuern Mehr!!! was emblazoned underneath the NRZ masthead from 19 November to 17 December 1848.

6o Marx 1977a, p. 6o6. Reflecting on the PNA in the summer of 1848 in April 1852, Engels wrote, 'the Assembly ... had long since forfeited any public esteem... had restored the obnoxious privileges of feudalism, and thus betrayed ... the interests of the peasantry. They had neither been able to draw up a Constitution, nor to amend in any way the general legislation'; Engels 1979, p. 66.

$61 \quad$ Huber 1960, p. $75^{6 .}$

62 In 1849.

63 The military were exempt, possibly an indirect bone of contention in their collection. 
and Erfurt all paid the Class Tax instead. The Milling \& Slaughter Tax yielded $2.1 \mathrm{~m}$ Thalers in $1849,7.5 \%$ of the indirect-taxes total.

Writing in September 1847 Marx said, 'the government ... in levying the Milling \& Slaughter Tax comes daily into direct contact with the proletariat and confronts it in hateful fashion. ${ }^{\prime} 4$ More recent critics are no less damning Mark Spoerer writes, 'an extreme example of the tax burden that was put on the poor is the notorious Prussian milling and slaughter tax',65 Huber regards it as 'clearly a retrograde step on taxation';66 Jonathan Sperber labels it 'highly unpopular' 67

The tax was certainly regressive - it was specific, or flat-rate, thus one Thaler per hundredweight of meat - at a time when between $60 \%$ and $80 \%$ of incomes in poor households was spent on food. Prussian wages in the $1840 \mathrm{~s}$ bottomed-out in 1847 but, as Marx points out in Wage Labour and Capital, did not then rise in tandem with sharply rallying cereals and meat prices in the winter of 1847 (and on into 1848). Moreover, there was no simple pass-through of the tax from producers (who physically paid it to the authorities) to consumers, who could pay mark-ups of as high as $90 \%$ in the case of rye flour, and a smaller but still meaningful $20 \%$ premium for wheat flour. ${ }^{68}$

The manifold unfairness of the Milling \& Slaughter Tax, then, was an issue likely to resonate easily with poorer Prussians, and Marx duly makes the most of it (the simple point that this tax gave rise to 'daily' conflict, unlike those collected monthly - such as the Class Tax - or annually, also makes it a more likely component of the campaign).

The campaign was very much intended to involve those most affected by the inequitable tax regime, and thus the rural poor. In a letter of 13 November 1848, Marx urges Ferdinand Lassalle to resolve at his meeting of the People's Club in Düsseldorf on a 'general refusal to pay taxes - to be advocated especially in rural areas' ${ }^{69}$ On 18 November, Marx writes in the $N R Z$ that 'the larger provincial towns, in particular the provincial capitals, can only be safeguarded through the revolutionary energy of the countryside. The refusal to pay taxes (whether direct or indirect) gives the countryside the best opportunity to serve the revolution:.$^{70}$ The first intention is to inspire coordinated civil disobedience, not the random acts of peasant violence seen, for example, in March

\footnotetext{
$64 \quad$ Marx 1976, p. 226.

65 Spoerer 2007, p. 59 .

66 Huber 1960, p. 214.

67 Sperber 1991, p. 327.

68 Spoerer 2007, p. 6o, citing Étienne Laspeyres.

69 Marx 1982, p. 180.

7o Marx 1977b, pp. 39-40.
} 
1848. On 18 November, Marx (along with Karl Schapper and Karl Schneider II) raised the stakes. In response to the authorities' stating force would be used to collect taxes, supporters were told 'their forcible collection must be resisted everywhere and in every way.'71

Marx also sought to attract and inspire broad-based social (and political) support. If he was first to urge non-payment of taxes, on 11 November 1848, Marx was soon followed even by erstwhile rivals such as Bonn professor and Bonner Zeitung editor Gottfried Kinkel who asked a mass meeting on 13 November in Bonn, 'with many peasants of the vicinity in attendance', 'How do you boycott taxes?' replying, 'You don't pay them'!2 Other newspapers, such as the more down-to-earth Freedom, Brotherhood, Labour [Freiheit, Brüderlichkeit, Arbeit], the organ of the Cologne Workers' Association, vigorously supported the campaign. ${ }^{73}$ While the rural population was intended to be the primary lever, 'committees of safety', 'people's committees' (Marx was elected to the one in Cologne on 13 November), 'citizens' committees' or 'People's Clubs' were set up in significant Rhineland towns such as Cologne, Düsseldorf, Koblenz, Trier, Bernkastel, Kreuznach, Cochem, Saarlouis and Bitburg. ${ }^{74}$

The campaign is frequently dismissed as ineffective and insignificant, a mere footnote to the German Revolutions. ${ }^{75}$ Oscar Hammen suggests that the crisis in Prussia was over a week after the Assembly called on the people to refuse to pay taxes', ${ }^{76}$ while Ernst Bammel argues, 'the call to tax refusal found practically no following at all. ${ }^{77}$ Lassalle, arrested on 22 November 1848 for his part in co-leading the Düsseldorf tax boycott, argued retrospectively that the campaign was 'without any real success.' ${ }^{78}$ Empirically, however, these observations are inaccurate. ${ }^{79}$

$71 \quad$ Marx 1977b, pp. 47, 41.

$72 \quad$ Sperber 1991, p. 325 .

73 See its issue of 19 November 1848: 'Tax refusal is the state of siege the people impose on the government'.

74 Sperber 1991, p. 325 .

75 By Ferdinand Lassalle, Oscar Hammen, Ernst Bammel, Hans-Ulrich Wehler, Veit Valentin, Manfred Botzenhart, Theodore Hamerow and Wolfgang Schwentker, amongst others; East German commentators Walter Schmidt and Gerhard Berger, and Jonathan Sperber are rare exceptions.

76 Hammen 1969, p. 350.

77 Becker 1963, p. 160.

78 Lassalle 1919, p. 90.

79 Regarding Hammen, for instance, an attempt by infantrymen on 26 November 1848 to arrest the organiser of tax-refusal in Bernkastel failed; Schmidt, Berger, Bleiber, Dlubek, Schmidt and Weber 1973, p. 238. 
There are certainly reports of tax boycotts outside the Rhineland - in Saxony and Silesia, in particular - but it is perhaps no coincidence that the greatest number of tax boycotts is reported in the heartland of the $N R Z$, the Rhineland. In Cologne itself, ${ }^{80}$ and in other garrison fortress towns, the strong military presence precluded tax boycotts. In many individual towns and in the (less easily policed) countryside, however, there were numerous instances of taxes not being collected, on single days, in the second half of November 1848 .

Marx identifies in the NRZ Bonn, Düsseldorf (the head of government there separately told Interior Minister Otto von Manteuffel on 18 November, 'taxes are no longer being paid in many places'), ${ }^{81}$ Wittlich (near Trier), Bernkastel, 'various country places' in the Rhineland, and Neheim (in Westphalia) as being tax-boycotters. ${ }^{82}$ Sperber adds (within the Rhineland) Ratingen (as does Erica Stubenhöfer), Gerresheim, Cochem, villages in the Moselle Valley and Aachen. Though not specifically cited by Sperber, Aachen senior privy counsellor von Solemaker told von Manteuffel on 20 November, 'we would have seen the bloodiest conflict here today if the main tax office hadn't foregone immediate payment of Milling \& Slaughter Tax.' ${ }^{83}$ Koblenz's governing vice-president told von Manteuffel that on 18 November, 'several items liable to Milling \& Slaughter Tax were brought in duty-free', a situation he says recurs on 20 November, although tax collection was restored the following day. ${ }^{84}$ Senior Privy Counsellor Birck advised von Manteuffel that Milling \& Slaughter Tax could not be collected in Bonn on 18 November, a possibility he had warned about the day before, although the arrival of an infantry battalion on 20 November restored collections (though 'little is being brought in', its commander reported on 21 November). ${ }^{85} \mathrm{Schmidt}$ (et al.) report instances of peasants in Magdeburg (in Saxony) refusing to pay taxes until a more populist Ministry is installed, of tax collection being 'violently resisted' (in Düsseldorf, in Frankfurt-an-der-Oder and Guben in Brandenburg, in Halberstadt in Saxony), of taxes being confiscated or not remitted in Silesian towns (Görlitz, Waldenburg and Striegau). ${ }^{86}$ Julius Pinder, the Oberpräsident of the Silesian province, supported the

\footnotetext{
8o $\quad$ Hansen 1976, p. 531.

81 Hansen 1976, p. 528.

82 Marx 1977b, pp. 39, 53; also varyingly cited by Sperber 1991, pp. 327-8, 331, 332-6; Hammen 1969, p. 347; Becker 1963, pp. 158, 160-1, 165 .

83 Hansen 1976, p. 542.

84 Hansen 1976, pp. 536, 546, 547 .

85 Hansen 1976, pp. 531, 537, 545, 550.

86 Schmidt individually adds reports on Silesian tax-refusal resolutions in Liegnitz, Schweidnitz, Neustadt, Ratibor and Glatz. See Schmidt 1979, p. 193.
} 
boycott, and was dismissed. ${ }^{87}$ Trier's senior privy counsellor Sebaldt told Prussia's Oberpräsident, Franz Eichmann, on 19 November that while the situation with direct taxes was 'bearable, 'with the Milling \& Slaughter Tax, it must soon come to conflict'.88

The $N R Z$ had a pervasive hand in the campaign, whether directly, through its own columns, or indirectly - placards were posted in both Trier and Prüm, in the Rhineland, citing the NRZ. Becker contends, of the tax boycotts as a whole, that 'part of these actions, above all in the Rhineland, can definitely be traced back to the effect of the NRZ' ${ }^{\prime} 9$

Spoerer argues that 'to my knowledge, throughout the nineteenth century, not one of the six largest German states modernised its fiscal structure in the course of revolutionary events or immediately afterwards, ${ }^{90}$ but this is surely contestable. Dr Ernst Engel, chief Prussian statistician from 1860, wrote in September 1863 of attempts in 1847 and 1848 to repeal the Milling \& Slaughter Tax, 'the motive mainly being the improvement of the situation of the working classes, whom one saw as disadvantaged by the Milling Tax. ${ }^{91}$ These were rebuffed (mainly through the vested interests of municipal authorities who would have had to replace this tax with one less palatable to themselves, and to wealthier tax-payers). Nonetheless, the number of towns participating in the Milling \& Slaughter Tax fell from 101 in 1848 to 88 a year later, and 83 from $185^{2}$ (cumulatively, removing c.150,00o ranking tax-payers). Under a law agreed in September 1849, and effective from May 1851 - the previous regressive arrangements driving 'the necessity of tax reform, ${ }^{92}$ in Dr Adolph Wagner's view - a revised Class Tax and a new Classified Income Tax [Klassifizierte Einkommensteuer], starting at an annual income of 1000 Thalers, were introduced.

Ultimately, the tax-boycott campaign was not sustainable for two reasons the inability of the PNA to maintain a united front, and the loyalty of the Prussian standing army. On balance, it is easy to designate the performance of the PNA as half-hearted throughout the tax-refusal campaign. The PNA deemed at its 11 November sitting that General Brandenburg (the head of King Friedrich Wilhelm IV's latest Ministry) 'has committed high treason'93 by dissolving the civic militia. An attempt at that sitting, though, by three Left

\footnotetext{
$87 \quad$ Hansen 1976, p. 543 .

88 Hansen 1976, p. 538 .

89 Becker 1963, p. 160.

$90 \quad$ Spoerer 2007, p. 64 .

$91 \quad$ Engel 1863, p. 218.

$92 \quad$ Wagner 1904, p. 73 .

93 Marx 1977b, p. 20.
} 
deputies to have the PNA endorse a tax boycott was rejected, ${ }^{94}$ and the PNA commission appointed that day to discuss tax refusal had to report three times before PNA deputies finally voted on a motion on 15 November, and that motion was watered-down, saying: 'the Brandenburg Ministry has no right ... to collect taxes'. ${ }^{95}$ This transferred the onus on actually not paying tax to the individual taxpayer (or, as Marx put it at his 8 February 1849 'tax refusal' trial, with the National Assembly not willing to go 'beyond passive resistance ... to give effect to the refusal to pay taxes the people had to take a revolutionary stand'). ${ }^{96}$

All that said, the PNA decree passed unanimously (by 226 votes) on 15 November, that 'so long as the National Assembly is not at liberty to continue its sessions in Berlin, the Brandenburg Ministry has no right to dispose of government revenues and to collect taxes, ${ }^{\prime}{ }^{97}$ undoubtedly had a material impact. The authorities were clearly alarmed by the vote and the calls not to pay taxes. Eichmann was moved to 'utter a serious warning against them'98 on 17 November, the Prussian Ministry unveiled 'forcible measures' a day later, and the Imperial Administrator [Reichsverweser] vowed on 21 November, 'I will not tolerate that resolution which endangers the welfare of all Germany by a cessation in the levying of tax in Prussia. ${ }^{99}$

The alarm, though, soon dissipated. PNA deputies, having at least provided a collective figurehead in mid-November 1848 , albeit offering no effective resistance to military challenges, gradually dispersed to their constituencies until there was only a rump parliament left in Brandenburg to be easily dissolved on 5 December.

Secondly, the Prussian Ministry was able to count on the continuing loyalty of the standing Prussian army. Some 1300 army reservists in Cologne did formally back the PNA, but this was little more than $10 \%$ of their total number. Around the country, some militiamen refused to don uniform; in the most flagrant incident, in Erfurt in Saxony, on 24 November, soldiers used artillery to restore control with seven rebelling militiamen being summarily executed. This superior military force available to the authorities was decisive, as Lassalle noted (if in 1862): 'the tax executor comes to me, I resist and throw him out of the door ... the tax executor returns, reinforced by soldiers. I resist once more, with my friends and household ... the soldiers open fire, wounding and killing.100

\footnotetext{
94 Schmidt, Berger, Bleiber, Dlubek, Schmidt and Weber 1973, p. 237.

$95 \quad$ Marx 1977b, p. 36.

$96 \quad$ Marx 1977b, pp. 338-9.

$97 \quad$ Marx 1977b, p. 36.

98 Marx 1977b, p. 37; compare Hammen 1969, p. 346.

99 Huber 1960, p. 759; Siemann 1998, p. 170.

$100 \quad$ Lassalle 1919, p. 92.
} 
Arguably, Marx and the NRZ did test the limits of what a democratic newspaper could effectively and realistically achieve in 1848. Marx scarcely takes the personal risks run by the arrested Wolff (in Brussels, in the Spring of 1848 'they tore off his glasses, spat in his face, punched him etc.') ${ }^{101}$ or Lassalle (in Düsseldorf prison - 'threats of slaps in the face, the dark cell and corporal punishment'). ${ }^{102}$ Marx did, though, end up facing trial in February 1849, twice. Prussian newspapers were frequently suppressed in 1848 and 1849, and he was ultimately expelled from Prussia in May 1849. Marx, the initial inspiration behind No More Taxes!!!, called for taxes to be boycotted on 11 November - six days before the PNA's 15 November vote took effect -, stiffened the backbone of the PNA, helped put together a broad-based coalition, and targeted those suffering most from the most regressive prevailing taxes. On 18 November, Marx (along with Karl Schapper and Karl Schneider II) urged fighting forcible collection of taxes in kind. Most importantly of all, perhaps, Marx did not just talk about boycotting taxes.

\section{Marx as Activist - or Not}

The No More Taxes!!! campaign sees Marx in a rare light, as a practical activist, a guise arguably brought about by an unusual combination of circumstances: acting out of character, being in the right place (or country), and working alongside those with similar motives and intentions.

Engels may have said of Marx, at the 1883 graveside speech, 'fighting was his element',103 but it is hard to misconstrue the combativeness. Marx was far more obviously thinker than fighter. Engels enjoyed being a combatant in his home town of Elberfeld in May 1849 - 'the NRZ, too, was represented at the Elberfeld barricades. ${ }^{104}$ He could boast a little later to Jenny Marx of his role in the June-July 1849 Baden uprising, 'I was in four engagements ... Enfin, I came through the whole thing unscathed, and au bout du compte, it was as well that one member of the NRZ was present, since the entire pack of democratic blackguards were in Baden and the Palatinate, and are now bragging about the heroic deeds they never performed'. ${ }^{105}$ Sperber writes of this period of 1849 , 'it is hard to know which was worse for the revolutionary movement, Marx's reluctance to take action or Engels' excessive willingness to do so'.106

\footnotetext{
101 Marx 1976, p. 581.

102 Marx 1977b, p. 346.

103 Engels 1989, p. 468.

104 Engels 1977, p. 447.

105 Engels 1982, p. 203.

106 Sperber 2013, p. 236.
} 
Marx moved to London for good in August 1849, but while 'life in exile was disorienting ... for the many scholars [Gelehrte] in the group,',107 the same could not be said of Marx's 'largely self-imposed' 108 isolation, Ashton suggests. In February 1851, Marx wrote to Engels, 'I am greatly pleased, by the public, authentic isolation in which we too, you and I, now find ourselves. It is wholly in accord with our attitude and our principles.'109 A fortnight earlier, fellow émigré Wilhelm Pieper had told Engels that 'Marx leads a very retired life'.110

The founding of the First International, the IWMA, in 1864 does offer renewed scope for practical activism for Marx, but this too founders through his geographic remoteness (he attended only one European Congress, in 1872), and disputes involving personalities and the politics.

Sperber appears keen to make a more sympathetic case, but titling a chapter in his 2013 Marx biography 'The Activist' sits oddly with the actual content of the 60 pages that follow. On the failure to consummate a Berlin newspaper with Lassalle, 'exile in England had become comfortable and familiar, too much so for a risky new venture in central Europe'. On Lassalle's political leadership, 'Marx ... once again found himself condemned to political passivity'. On the IWMA congresses, with their 'unpredictable' outcomes, Marx 'always heaved a sigh of relief when the congresses were over.'11

Nor, as the dust jacket of the Sperber biography claims for its treatment, does it seem altogether convincing that 'Marx no longer is the Olympian soothsayer ... but a scholar-activist'. This is not least because in the body of the text, Sperber writes: 'countless twentieth-century Marxist activists, including Lenin, eagerly adopted the hallmarks of the professional revolutionary, continuous single-minded conspiracy and agitation, but Marx never did. Neither Marx's professorial demeanour, nor his scholarly interests, nor his family commitments and the financial demands they made upon him fit these requirements' ${ }^{112}$

But Sperber does proclaim the activist passion of the No More Taxes!!! campaign. 'Marx threw himself wholeheartedly into the fight. Every day, the masthead of the New Rhineland News proclaimed: "No More Taxes!!!" ... Marx used his position on the directory of the provincial federation of democratic clubs in November to organise both a tax boycott and then armed resistance to the

\footnotetext{
107 Ashton 2013, p. 23.

108 Ashton 2013, p. 98.

109 Marx 1982, p. 286.

110 Marx 1982, p. 269.

111 Sperber 2013, pp. 383, 347, 354, 361.

112 Sperber 2013, p. 157.
} 
Prussian government across the length and breadth of the Rhine Province, with wide support from the region's democrats and broad public approval.: ${ }^{113}$

\section{Wolff's Distinctive Contribution}

Wilhelm Wolff, or 'Lupus', was a close associate of Marx from their time together in the Brussels suburb of Faubourg St Lauvain in 1846, until his death from meningitis in 1864 .

Wolff brings three distinctive dimensions to the tax campaigning of the Marx inner circle. First, while Marx does spearhead in No More Taxes!!! an attack on one specific tax, the Milling \& Slaughter tax, the attack is broad-brush. Wolff, in contrast, details the precise financial incidence of his target, the Class Tax. Where Marx one-sidedly champions the rural poor, Wolff presents the issue of tax as one of class antagonism, the mechanism whereby the peasant is exploited by the Junker. If these first two observations imply that Wolff's approach is drier and more cerebral, his final distinctiveness lies in the easy accessibility of his style, his 'common touch' for a peasant readership. ${ }^{114}$

Wolff's leading $N R Z$ article on 15 December 1848, Why The People Pay Taxes, ${ }^{115}$ is a polemical vanguard to his Silesian Milliard of the following spring. Wolff's skill in Why The People Pay Taxes lies in his ability to extract damning case studies from an otherwise dry committee report on Prussian financial administration, undertaken between 1 July 1847 and 31 December 1848 . The report appears to have been leaked, since its publication was banned ${ }^{116}$ by General Friedrich von Wrangel, who was instrumental in the counter-revolutionary coup d'état that dissolved the PNA on 5 December 1848.

After explaining that the report clarifies how 'the pockets of the people have been picked for the gratification' of an army of overpaid state officials, ${ }^{117}$ Wolff targets in particular Count von Keller:

While thousands of poor children are stunted in body and soul by the lack of life's necessities, district magistrate Count von Keller receives each year 300 Thalers ${ }^{118}$ for the upbringing of his three children - he gets them, not from the pocket of the King, but from the tax pennies of the poor. Mr Count von Keller has, to be fair, his pretty salary, but when a count has three children, it goes without saying that the poor, starving

\footnotetext{
113 Sperber 2013, p. 231.

114 Sperber 1991, p. 299.

115 Wozu das Volk Steuern Zahlt.

116 Schmidt 1979, p. 197.

117 Ibid.

118 A poor day-labourer might earn 60 to 8 o Thalers annually; Wolff 1886, p. 46.
} 
rabble must divvy up 300 Thalers a year for the upbringing of the countly children. Our ordained constitution has it that you can only vote for the second chamber, if you're not getting support from the public purse. Does this mean Mr Count Keller is going to lose the right to vote? Oh phooey for asking this uncharitable question.

Count von Keller is by no means the only target. In the following paragraphs, Wolff rounds on Colonel von Lengefeld - 'if you've got children, and only 1000-2000 Thalers to rub along on each year' - and then a succession of nobles and state officials receiving annual subsidies.

The sums here are not huge, and the tone perhaps excessively knockabout, but Wolff has a serious conclusion to make: 'so will the stupid people finally understand, that it is solely born to pay taxes, and its highest honour rests in the fattening of the privileged class.'119

Wolff's The Silesian Milliard [Die Schlesische Milliarde] ${ }^{120}$ is altogether more heavyweight, a sustained attack on regressive taxes, such as the Class Tax, in a series of nine lead NRZ articles between 22 March and 25 April 1849. The Silesian Rustical Alliance distributed 10,000 copies of the issues carrying the articles $^{121}$ (the NRZ itself sold 20,000 copies on its final day of publication, 19 May 1849, but had a peak circulation otherwise of 6,000 - by comparison, the 1848 weekly sale of the Manchester Guardian was just over 9,00o copies). ${ }^{122}$ Schmidt regards The Silesian Milliard as 'the highpoint in Wolff's overall political and journalistic output. It is his most comprehensive and best Marxist work'. Engels, in his 1876 tribute to Wolff, claims of The Silesian Milliard, 'few of the many inflammatory articles in the $N R Z$ had such an effect as these.'123 Prussian Interior Minister von Manteuffel regarded the NRZ's April 1849 articles, notably The Silesian Milliard (and Marx's Wage Labour and Capital) as sufficiently inciting that he sent them to the Justice Ministry, with a view to instigating a legal prosecution. ${ }^{124}$

119 Neue Rheinische Zeitung 1973, p. 908.

120 The 'Silesian Milliard' was Wolff's estimate of how much the 'robber knights' had underpaid in tax in the preceding 20 years, a figure he put at 300 million Thalers, being an equivalent echo of the 1000 million francs - or milliard - extracted from 'the French peasant'; Engels 1989, pp. 148-9; Engels 1990a, p. 351; Wolff 1886, p. 30.

121 See Mehring 1936, p. 186: 'On the 2oth of March ... the Neue Rheinische Zeitung had begun to publish Wilhelm Wolff's articles on the Silesian milliards which so aroused the rural proletariat ...'

122 Hutt 1966, p. 152.

123 Engels 1989, p. 146.

124 Schmidt 1979, p. 207. 
Schmidt claims that 'the agrarian question was precisely in these months one of the neuralgic points, which the revolutionary party had to capitalise on ... the peasantry was discontented in the extreme and found itself in a mood of revolutionary agitation ... Wolff's articles show the efforts of the $N R Z$ to draw the peasantry into the revolutionary fight.'.125 The Silesian Milliard and, in a more diffused way, the No More Taxes!!! campaigns show that with the right grievance(s), the right journalistic stimulus (if Wolff, 'formerly himself son of a smallholder, ${ }^{\prime 26}$ more obviously than Marx) and the right organisation on the ground (Silesia's Rustical Alliance, with its 200,00o registered members), Marxism could appeal successfully to the peasantry.

The Silesia of Wolff's The Silesian Milliard was the most populous province in Prussia, with 3.1m inhabitants in 1849 (19\% of the then $16.3 \mathrm{~m}$ Prussian total, or close on $10 \%$ of the 'German' total), positioned at the most extreme ends of then Prussian society: the largest number of the worst paid day-labourers (c.186,00o male, 138,00o female) on the one hand, the biggest and richest number of landed estates on the other. ${ }^{127}$

While also criticising the Land Tax [Grundsteuer] and Federal Caution Money [Schutzgeld], ${ }^{128}$ Wolff rails most forcefully against the Class Tax, described by historian Huber as 'something between a poll tax and an income tax'129 and by Prussian statistician Carl Dieterici as 'a personal tax on everybody'.130 Established by an initial law of 30 May 1820, Class Tax was payable by all Prussians from 16 to 60 (with some exemptions), across four main classes, and 12 principal sub-classes, at a rate varying between one half and 72 Prussian Thalers per individual (the relatives rather than the modern monetary equivalents matter most to this discussion). It did not rely on 'a numerically measured income ... but rather according to general indications of approximate wealth and ability to pay in the class in question. ${ }^{131}$ The Class Tax raised $7.6 \mathrm{~m}$ Thalers, or $11 \%$ of the Prussian Finance Ministry total tax-take, in 1849 .

125 Schmidt 1979, pp. 199, 203. Strey and Winkler 1972, p. 270, make similar claims: 'it's clear that the $N R Z$ in this current phase of preparation for the social-republican revolution sought to establish the alliance with all the peasants'.

126 Schmidt 1979, p. 198.

127 Obermann 1977, pp. 73-4.

128 Feudal dues are separately attacked in the $N R Z$ in June 1848 - 'one cannot understand why there has not been a peasant war long ago in the old-Prussian provinces'; Marx 1977a, p. 117 .

129 Huber 1957, p. 213.

130 Dieterici 1849, p. 104.

131 Wagner 1904, p. 67. 
The second chapter of The Silesian Milliard is entitled, simply, Die Steuern [The Taxes]. Wolff makes the case for what he sees as the brazen inequity of the Class Tax formula:

Let's pluck someone out from the masses. He owns eight Morgen ${ }^{132}$ of land of middling quality, pays a host of tithes annually to his 'gracious' lord, must perform a large amount of statute labour for him every year, and still has to pay Class Tax of seven Silver Groschen and six Pfennigs monthly, or three Thalers annually. Contrasted with him, we have a 'gracious' lord with the most extensive estates, with forests and meadows, iron-works, zinc ore mines, coal mines etc. - as an example, the archwailer, Russophile, feaster on democrats and Deputy to the Second Chamber, Count Renard. This man has an annual income of 240,000 Thalers. He sits on the highest rung of the Class Tax, paying no more than 12 Thalers monthly, or 144 annually. Compared with the rustic tenant with the eight Morgen, he should have been paying at least 7,00o Thalers in Class Tax annually.133

(As with Count von Keller, in Why The People Pay Taxes, Wolff omits any biographical gloss here. The Count Renard to whom he refers is the 54-year-old Count Andreas Maria von Renard; the Second Chamber came into being on 26 February 1849. The argument that the Count should be paying, proportionate to his income, 7,00o Thalers annually in Class Tax makes sense if the 'rustic tenant' is earning $c .100$ Thalers annually.)

Wolff then sets the lowliest inhabitants of Prussia ('let's linger for a moment on the very bottom rung of the Tax') $)^{134}$ alongside the 'gracious' Count:

A farmhand with a yearly wage of 10 Thalers pays the State from this annual income half a Thaler in Class Tax, or $5 \%$ of his ready income. Good Count Renard dispenses from his 240,00o Thalers in annual income only 144 Thalers ... that means, the farmhand pays annually proportionately 83 times as much as the noble Count Renard. ${ }^{135}$

In the lowest class, the farm-maid pays out of her annual wage of six Thalers just the same half a Thaler, or $8.33 \%$ of her income. In the same,

\footnotetext{
132 Around five acres.

133 Wolff 1886, p. $3^{2}$.

134 Ibid.

$1355 \%$ being $83 x$ greater than the actual $0.06 \%$ of annual income which the Count pays in Class Tax.
} 
not remotely progressive relationship to the farm-maid, Count Renard would have had to pay 20,000 Thalers annually.

Wolff's central contention on the Class Tax was irrefutable, as all Prussia's bestknown statisticians concluded. Dieterici, commenting on the first range of Class Tax tariffs (when the ratio of bottom-to-top payments was 1:48, against the still inadequately revised 1:144 introduced in 1821) wrote 'by far, this does not correspond to the difference in income circumstances; there could be rich estate-owners with incomes of 10,000 Thalers, thus 100x as great as the daylabourer earning 100 Thalers'.136 Since, at the end of the same report, he wrote 'the execution of the communist idea of an identical distribution of all property, apart from its immoral, rashly criminal conception ..., ${ }^{137}$ Dieterici could hardly be described as sympathetic to Wolff. Dr Ernst Engel commented retrospectively in 1868 that 'the Class Tax proved in relation to the upper classes consistently indefensible ... since the richest of all paid relatively the least'.138 Dr Wagner, in 1904, commenting on the near $50 \%$ contribution to the overall Class Tax tax-take in the late 1840 s by the poorest main class, wrote 'the tax burden has progressively fallen ... on the lower class ... the necessity of tax reform in 1851 ... is thereby proven.'. ${ }^{139}$ Reflecting on Class Tax in the late 1840 , economist Hill wrote 'a minimum annual rate of half a Thaler and a maximum of 144 Thalers could not correspond to the wide difference between the incomes of the poorest and those of the richest tax-payers. If the former rate was just, the latter was altogether too low ... such taxation, while a considerable burden for the poor, bore very lightly on the well-to-do and hardly at all on the very wealthy.'.140

\section{Why Later Marxists Have Not Engaged with Tax, and Why They Should}

Münster-based Marxist sociology journal Prokla commendably devoted an entire issue in March 2009 to tax, but with the apologetic introductory remark, 'For the Left, taxes were only rarely a subject worthy of discussion. ${ }^{141}$ Why has this been the case, and more specifically, why have Marxists not engaged with

\footnotetext{
136 Dieterici 1849, p. 105 .

137 Dieterici 1849, p. 112.

138 Engel 1868, p. 26.

139 Wagner 1904, p. 73.

140 Hill 1892, pp. 211-12.

141 Prokla 2009, p. 2.
} 
'Marx on tax'? Most obviously, tax is not treated, comprehensively, in any of the major self-contained political-economy texts of Marx and Engels. Instead, it is covered piecemeal, predominantly in their journalism, occasionally in their letters (and in some discrete texts). Engels's Elberfeld speech, for example, first appeared in an 1845 Rhineland annual which also included poems by Georg Weerth. ${ }^{142}$ But it has always seemed unreasonable to dismiss the importance of their journalism, which appeared, meaningfully, in over 25 newspapers from 1839 to 1894 (for seven of which, between 1842 and 1859, Marx and Engels were the formal or de facto editors). ${ }^{143}$ Their journalism fills fifteen volumes of the 50 Marx/Engels Collected Works (MECW), ${ }^{144}$ their letters, meanwhile, a further twelve MECW volumes. As acknowledged in the Introduction, state finances have attracted Marxists' attention, but, as O'Connor implies, with an emphasis on spending rather than funding, '... the left has not exploited the tax issue because it has been wedded to the modern liberal tradition that has sought an enlarged government role in the economy and has paid little or no attention to the structure and burden of taxation.'145 Other Marxist economists, even some of the best-known, seemed to have shared the Prokla conclusion, that 'taxes were only rarely a subject worthy of discussion'. Paul Sweezy hints at engagement, and with the century of Marx and Engels, in his The Theory of Capitalist Development. 'Throughout the nineteenth century', he writes, 'the tax structure in all capitalist countries was highly regressive in its incidence' but taxation turns out to be one of 'many important topics' in his book which 'have been passed over with no more than a brief reference.' ${ }^{146}$ This was surely an oversight.

\section{Applying Marx-Engels Tax Policies to our Own Era}

There are, of course, many scoping issues to be addressed by any Marxists wishing to engage with tax. Although in the UK (the focus now), just two types of tax - income tax, including National Insurance (45\%) and VAT (18\%) account for nearly two-thirds of the projected approximately $£_{737}$ bn National Accounts tax base in 2018-19, tax can be enormously complex. The UK tax code (Tolley's Yellow \& Orange tax handbooks) runs to over 21,00o pages. The

\footnotetext{
142 Rheinische Jahrbücher zur gesellschaftlichen Reform.

143 Rheinische Zeitung; Deutsch-Französische Jahrbücher; Vorwärts!; Deutsche-Brüsseler Zeitung; Neue Rheinische Zeitung; Politisch.-ökonomische Revue; Das Volk.

144 Author's analysis.

145 O'Connor 1973, p. 235.

146 Sweezy 1942, pp. 233, v.
} 
IF S's Mirrlees Review of 2010-11 was an attempt at 'Reforming the Tax System for the 21st Century'; together, its two volumes exceed 1,900 pages. Any Marxist contribution to UK tax policy will require the input of tax experts.

This input will need to consider what should, and should not, be included. Bearing in mind the strictures of Marx and Engels on land-value tax, should any reform of property taxation (if not LVT, measures to re-band council tax, increase affordable housing, reduce offshore ownership, for instance) in a noncommunist world be contemplated? How far should taxes either negligible ('profits tax', or Gewerbesteuer, provided just $3 \%$ of the 1849 Prussian tax take, ${ }^{147}$ for instance) in the nineteenth-century or unknown to Marx and Engels (both corporation and capital-gains tax were only introduced in 1965 in the UK) be assessed? The 'tax gap' - the difference between what HMRC should and does collect - is huge (put at $£_{33}$ bn by HMRC itself, at around £12obn by tax analyst Richard Murphy) but arises for Marx and Engels explicitly only through their tacit endorsement of evasion. The parameters of Marxist taxation policy would need to draw on many such contributory qualifications.

But Marx and Engels themselves provide a starting point. Many of the taxpolicy proposals and preferences aired by Marx and Engels in the nineteenth century, and discussed in this essay, have a contemporary application. Wealth in the UK is far more unequally distributed than income, with a Gini coefficient, per the Office for National Statistics (ONS) in 2018, of 0.62 for wealth, ${ }^{148}$ against 0.35 for gross income $\mathrm{e}^{149}$ (1.o being maximum inequality). According to the 2018 World Inequality Report, the richest $1 \%$ control $22 \%$ of Britain's wealth, up from $15 \%$ in 1984 . Engels's 'general, progressive tax on capital' could be brought to bear on this wealth imbalance, and in practical ways. Of the $£_{12.7}$ trillion of wealth held by private households in Britain, as reported by the ons, the largest proportion, $42 \%$, is accounted for by private pensions (property wealth accounting for a smaller $36 \%$ share). Pension tax relief, including National Insurance relief on employer contributions, was set to cost $£_{3} 8.6 \mathrm{bn}$ in 2017.

The demand of Marx and Engels, in their 1848 Manifesto (and frequently elsewhere) for a 'heavy progressive or graduated income tax' is easily addressable. Currently, the highest rate of UK income tax is $45 \%$ (levied on incomes

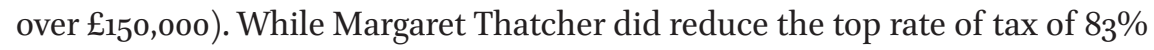
after her election as prime minister in 1979, she was happy to leave it at $60 \%$ until 1988.

147 Dieterici 1853, p. 29.

148 Office for National Statistics 2018b.

149 Office for National Statistics 2018a. 
Indirect taxes, the long-running preference of Marx and Engels, are expected to account for $28 \%$ of the UK total tax take in 2018-19. The poorest UK households currently pay twice as much of their disposable income in indirect taxes (thus VAT, duties on alcohol, tobacco, fuel) as the richest $(30 \%$ vs $15 \%),{ }^{150}$ a clear driver of net income inequality. While relaxing measures against alcohol, tobacco - or sugar - may not be desirable, vAT (at £132bn) accounts for the greater (63\%) share of projected 2018-19 indirect tax revenue. According to the ons, again, 'the proportion of disposable income that is spent on VAT is highest for the poorest fifth and lowest for the richest fifth.' ${ }^{151}$ No UK political party formally committed in the 2017 General Election to a cut in the current $20 \%$ VAT rate, ${ }^{152}$ although when the UK leaves the EU (and its Single Market), it will no longer be obliged to levy the statutory EU minimum VAT rate of $15 \%$.

Marx's call for increased, progressive inheritance tax was tempered in 1869 by the suggestion that the first $£_{50}$ of inheritance should be tax-free. Whether one calculates a present-day value for that $£_{50}$ with reference to inflation (it becomes c.£4,00o) or to 'economic power' (measuring income or wealth relative to the total output of the economy), when it rises to $c . £ 96,000$, this is still a long way below the current UK nil-rate band of $£ 650,000$. The OECD in its 2018 report, The Role and Design of Net Wealth Taxes in the OECD, favoured the use of inheritance taxes to reduce wealth inequality.

At Elberfeld, Engels proposed 'the general education of all children ... at the expense of the state - an education which is equal'. Currently vat is not imposed on the fees of UK private schools, which are also exempt from business rates.

The issue of under-reporting personal (Marx) and corporate (Engels) tax liability, again policy areas in which reform would notably address inequality, has already been discussed.

Tony Atkinson wrote in his 2015 book, Inequality (and in the space of just 12 lines), 'In this chapter, ${ }^{153}$ I put forward a set of proposals for a more progressive structure of the personal income tax; for the preferential treatment of earned income; for radical reform of inheritance taxation; for the modernisation of property taxation ...; for the revival of the idea of an annual wealth tax; for global taxation ... for the reverse of the recent tendency to raise taxes on

\footnotetext{
150 Office for National Statistics 2017.

$15^{1}$ Ibid.

$15^{2}$ Labour Shadow Chancellor John McDonnell would consider a vaT reduction, depending on 'how the economy grows'; Observer 2017.

153 Titled 'Progressive Taxation'.
} 
consumption.154 Drawing on the inspiration of Marx and Engels, there seems no reason why modern Marxists cannot aspire to this scale of ambition.

\section{Conclusion}

This essay has had two main aims. First, to demonstrate that Marx and Engels did address tax, not merely in British Museum notes, but especially in numerous journalistic articles and letters, and in the campaigning in which Wolff was also prominent in 1848-9. Second, to show that their tax policies are by no means anachronistic curiosities but are perfectly applicable by modern Marxists to our own era.

There is a frequent defeatism about tax reform, whether it involves tax increases or redistribution. The UK of today is, undeniably, more heavily taxed than the UK or Prussia were in the century of Marx and Engels, but it is, relatively, not highly taxed.

The OECD's Revenue Statistics 2018 ranked the UK twentieth out of 36 OECD countries in terms of its tax-to-GDP ratio, at 33.3\%, well below that of France $(46.2 \%)$, Italy $(42.4 \%)$ or Germany $(37.5 \%)$. Among principal tax rates, those in the UK are well below historic highs, be it income tax (highest marginal rate of around $90 \%$ in the 1950 s and 1960 s versus $45 \%$ today), corporation tax (a nominal main rate of $52 \%$ in the 1970 s versus $17 \%$ from 2020 ), inheritance tax (highest marginal rate of $85 \%$ in 1969 versus $40 \%$ today) or capital-gains tax (40\% a decade ago, $28 \%$ on property today).

Nor should the continuing period of austerity preclude tax rises. The period during which (first) Engels and then Marx formulated their commentary on tax, 1839 until the early 1890 s, included four financial crises $(1847,1857,1866$, and the Long Depression of 1873-96). More recently, UK tax receipts as a percentage of GDP, according to овR data, fell back to $35.2 \%$ in $2009-10$, in the wake of the 2008 financial crash, but have steadily risen since, to a projected $37.0 \%$ in $2018-19$.

Independent tax commentators have been less sanguine about the declining absolute 'tax gap' (the proportion of total tax liabilities not actually captured) than HMRC, which has reported a fall in the gap from $7 \cdot 9 \%$ in $2005^{-6}$ to $5 \cdot 7 \%$ in 2016-17. There has, though, been encouraging evidence of concerted initiatives and action (including fines) by international bodies such as the OECD, IMF and EU to address profit-shifting by multi-nationals (especially technology companies), estimated to cost between $4 \%$ and $10 \%$ of global corporate

154 Atkinson 2015, p. 179. 
income-tax revenues, or $\$ 100-24$ obn annually. Leaked tax data such as the Panama and Paradise Papers have thrown light on tax avoidance by individuals.

Against this generally supportive backdrop, the issue of property taxation remains a potential missed Marxist opportunity, based on the principled opposition to Land Value Tax expressed by Marx and Engels. Marx's observation on The New English Budget in 1857, 'now, if taxes are not to be raised by customs and excise duties, they must be directly derived from property and income', ${ }^{155}$ clearly delineates property as a component of direct taxation, and thus points to some ambivalence. With the oNs estimating UK property wealth at $£_{4.5}$ trillion, but UK property taxes (council tax, stamp-duty land tax, and - dominated by property - inheritance tax) projected to be only c.£52bn in $2018-19$, barely $1 \%$ of the property-wealth aggregate, property cannot be overlooked.

If 'what concrete form taxes take is ... the crux of political conflict in any society', 156 tax matters.

\section{References}

Ashton, Rosemary 2013 [1986], Little Germany, London: Faber.

Atkinson, Anthony 2015, Inequality, Cambridge, MA: Harvard University Press.

Becker, Gerhard 1963, Karl Marx und Friedrich Engels in Köln, 1848-1849, Berlin: Rütten \& Loening.

Daily Mail 2017, 'Proud of Yourselves?', 14 December: 1.

Dieterici, Carl 1849, 'Über die Resultate der Klassensteuer im Preussischen Staate', Mittheilungen des Statistischen Bureaus in Berlin, I, 7: 103-12.

Dieterici, Carl 1853, Tabellen und Amtliche Nachrichten über den Preussischen Staat für das Jahr 1849, Bd. 4, Berlin: A.W. Hayn.

Engel, Ernst 1863, 'Resultate der Mahl- und Schlachtsteuer in der Periode von 1838 bis 1861', Zeitschrift des Königlichen Preussischen Statistischen Bureaus, 3, 9: 217-34.

Engel, Ernst 1868, 'Die Ergebnisse der Klassensteuer, der klassificirten Einkommensteuer und der Mahl- und Schlachtsteuer im Preussischen Staate', Zeitschrift des Königlichen Preussischen Statistischen Bureaus, 8, 1-3: 25-84.

Engels, Friedrich 1975a [1920], 'Letter to Friedrich Graeber', in Marx/Engels Collected Works, Volume 2, Moscow: Progress Publishers.

Engels, Friedrich 1975b [1845], 'Speeches in Elberfeld', in Marx/Engels Collected Works, Volume 4, Moscow: Progress Publishers.

155 Marx 1986b, p. 202.

156 Piketty 2014, p. 494. 
Engels, Friedrich 1976 [1969, 1914], 'Draft of a Communist Confession of Faith'; 'Principles of Communism', in Marx/Engels Collected Works, Volume 6, Moscow: Progress Publishers.

Engels, Friedrich 1977 [1849], 'Elberfeld', in Marx/Engels Collected Works, Volume 9, Moscow: Progress Publishers.

Engels, Friedrich 1979 [1852], 'The Prussian Assembly', in Marx/Engels Collected Works, Volume 11, Moscow: Progress Publishers.

Engels, Friedrich 1982 [1976, 1913], 'Letter to K. Marx, 23 February 1845'; 'Letter to J. Marx, 25 July 1849', in Marx/Engels Collected Works, Volume 38, Moscow: Progress Publishers.

Engels, Friedrich 1987 [1878], Anti-Dühring, in Marx/Engels Collected Works, Volume 25, Moscow: Progress Publishers.

Engels, Friedrich 1989 [1876, 1883], 'Wilhelm Woolf'; 'Karl Marx's Funeral', in Marx/ Engels Collected Works, Volume 24, Moscow: Progress Publishers.

Engels, Friedrich 1990a [1885, 1886, 1887], 'Preface to the First German Edition of The Poverty of Philosophy'; 'On the History of the Prussian Peasants'; 'Lawyers' Socialism', in Marx/Engels Collected Works, Volume 26, Moscow: Progress Publishers.

Engels, Friedrich 1990b [1901], 'A Critique of the Draft Programme of 1891', in Marx/ Engels Collected Works, Volume 27, Moscow: Progress Publishers.

Engels, Friedrich 1992 [1924], 'Engels to Bernstein, 22 September 1882, 8 February, 10 February 1883', in Marx/Engels Collected Works, Volume 46, Moscow: Progress Publishers.

Engels, Friedrich 2001 [1921], 'Engels to Hermann Engels', in Marx/Engels Collected Works, Volume 49, Moscow: Progress Publishers.

George, Henry 1966 [1879], Progress and Poverty, London: Hogarth.

Hammen, Oscar 1969, The Red 48-ers, New York: Scribner.

Hammond, Philip 2017, 'Labour's Garden Tax Will Hit 10 Million Households: Philip Hammond Warns of Labour's Local Levy “Bombshell”, Sunday Telegraph, 4 June.

Hansen, Joseph (ed.) 1976, Rheinische Briefe und Akten zur Geschichte der Politischen Bewegung 1830-1850, Bd. 2, Cologne-Bonn: Peter Hanstein.

Harvey, David 2017, Marx, Capital and the Madness of Economic Reason, London: Profile. Hill, Joseph 1892, 'The Prussian Income Tax', The Quarterly Journal of Economics, 6, 2: 207-26.

Hollander, Samuel 2004, 'Economic Organisation, Distribution and the Equality Issue: The Marx-Engels Perspective', The Review of Austrian Economics, 17, 1: 5-39.

Huber, Ernst 1957, Deutsche Verfassungsgeschichte seit 1789, Bd. 1, Stuttgart: W. Kohlhammer Verlag.

Huber, Ernst 1960, Deutsche Verfassungsgeschichte seit 1789, Bd. 2, Stuttgart: W. Kohlhammer Verlag. 
Hutt, Allen 1966, 'Karl Marx as a Journalist', Marxism Today, 5: 144-53.

Krätke, Michael 2006, 'Marx als Wirtschaftsjournalist', Beiträge zur Marx-EngelsForschung, New Series, 29-98.

Krätke, Michael 2009, 'Kritik der Öffentlichen Finanzen - Die Finanzkrise des Staates erneut betrachtet', Prokla, 154:1-177.

Lassalle, Ferdinand 1919, Gesammelte Reden und Schriften, Bd. 2, Berlin: Paul Cassirer.

Mandel, Ernest 1974, Marxist Economic Theory, London: Merlin Press.

Marx, Karl 1976 [1847, 1848, 1849, 1932], The Poverty of Philosophy; 'The Communism of the Rheinischer Beobachter'; 'Moralising Criticism and Critical Morality'; 'Wages'; Manifesto of the Communist Party; 'Notes on the Arrest, Maltreatment and Expulsion of Wilhelm Wolff', in Marx/Engels Collected Works, Volume 6, Moscow: Progress Publishers.

Marx, Karl 1977a [1848], 'Patow's Redemption Memorandum'; 'The Bill on the Compulsory Loan and its Motivation'; 'Reply of Frederick William IV to the Delegation of the Civic Militia'; 'Notes', in Marx/Engels Collected Works, Volume 7, Moscow: Progress Publishers.

Marx, Karl 1977b [1848, 1849], 'Decision of the Berlin National Assembly'; 'Impeachment of the Government'; 'No More Taxes!!!; 'A Decree of Eichmann's'; 'Tax Refusal and the Countryside'; 'Appeal'; 'On the Proclamation of the Brandenburg-Manteuffel Ministry about Tax-Refusal'; 'State of Siege Everywhere'; 'The Bourgeoisie and the Counter-Revolution'; 'The Trial of the Rhenish District Committee of Democrats'; 'Lassalle'; 'Prussian Financial Administration under Bodelschwingh \& Co.', in Marx/ Engels Collected Works, Volume 8, Moscow: Progress Publishers.

Marx, Karl 1977c [1849], 'Wage Labour and Capital', in Marx/Engels Collected Works, Volume 9, Moscow: Progress Publishers.

Marx, Karl 1978 [1850], The Class Struggles in France; 'Address of the Central Authority to the League'; 'É. de Girardin, le Socialisme et L'Impôt', in Marx/Engels Collected Works, Volume 10, Moscow: Progress Publishers.

Marx, Karl 1979 [1853], 'L.S.D, or Class Budgets, and Who's Relieved by Them', in Marx/ Engels Collected Works, Volume 12, Moscow: Progress Publishers.

Marx, Karl 1982 [1913, 1929, 1948], 'Marx to Ferdinand Lassalle, 13 November 1848'; 'Marx to Engels, 27 January 1851, 11 February 1851', in Marx/Engels Collected Works, Volume 38, Moscow: Progress Publishers.

Marx, Karl 1985a [1866], 'Instructions for the Delegates', in Marx/Engels Collected Works, Volume 20, Moscow: Progress Publishers.

Marx, Karl 1985b [1869, 1960], 'Report of the General Council on the Right of Inheritance'; 'Record of Marx's Speech on the Right to Inheritance', in Marx/Engels Collected Works, Volume 21, Moscow: Progress Publishers.

Marx, Karl 1985c [1930], 'Marx to Engels, 12 June 1863', in Marx/Engels Collected Works, Volume 41, Moscow: Progress Publishers. 
Marx, Karl 1986a [1902-3], 'Introduction to Economic Manuscripts of 1857-58', in Marx/ Engels Collected Works, Volume 28, Moscow: Progress Publishers.

Marx, Karl 1986b [1857], 'The New English Budget', in Marx/Engels Collected Works, Volume 15, Moscow: Progress Publishers.

Marx, Karl 1987 [1934], 'Marx to Hermann Jung, 20 November 1865', in Marx/Engels Collected Works, Volume 42, Moscow: Progress Publishers.

Marx, Karl 1992 [1891-2], 'Letter to Friedrich Sorge, 20 June 1881', in Marx/Engels Collected Works, Volume 46, Moscow: Progress Publishers.

Marx, Karl and Friedrich Engels 1989 [1891], Critique of the Gotha Programme, in Marx/ Engels Collected Works, Volume 24, Moscow: Progress Publishers.

Marx, Karl and Friedrich Engels 1996 [1867], 'Dedicated to my Unforgettable Friend'; 'Genesis of the Industrial Capitalist', in Marx/Engels Collected Works, Volume 35, Moscow: Progress Publishers.

Mason, Paul 2017, 'The AfD's Breakthrough in Germany Shows That It Is Time for Parties of the Left to Get Radical', Guardian G2, 26 September: 5 .

Mehring, Franz 1936, Karl Marx: The Story of His Life, London: George Allen \& Unwin. Neue Rheinische Zeitung 1973 [1848], Glashütten im Taunus: Detlev Auvermann.

Obermann, Karl 1977, 'Wähler und Wahlmänner, Ihre Soziale Herkunft und Ihre Beteiligung an den Wahlen 1848 in Schlesien', Jahrbuch für Wirtschaftsgeschichte, 1: $73-83$.

Observer 2017, 'Labour Pledges VAT Cut to Help Families on Low Incomes', 3 June.

O'Connor, James 1973, The Fiscal Crisis of the State, New York: St Martin's Press.

Office for National Statistics 2017, Effects of Taxes and Benefits on UK Household Income: Financial Year Ending 2017, available at: <https://www.ons.gov.uk/people populationandcommunity/personalandhouseholdfinances/incomeandwealth/ bulletins/theeffectsoftaxesandbenefitsonhouseholdincome/financialyearending 2017\#indirect-taxes-increase-inequality-of-income $>$.

Office for National Statistics 2018a, Household Disposable Income and Inequality in the UK: Financial Year Ending 2017, available at: <www.ons.gov.uk/peoplepopulation andcommunity/personalandhouseholdfinances/incomeandwealth/bulletins/ householddisposableincomeandinequality/financialyearending2017>.

Office for National Statistics 2018b, Wealth in Great Britain Wave 5: 2014 to 2016, available at: <www.ons.gov.uk/peoplepopulationandcommunity/personalandhouse holdfinances/incomeandwealth/bulletins/wealthingreatbritainwave5/2014to2016\# main-points $>$.

Piketty, Thomas 2014, Capital in the Twenty-First Century, Cambridge, MA: Harvard University Press.

Prokla 2009, Issue 154, pp. 1-177.

Schmidt, Walter 1979, Wilhelm Wolff, Kampfgefährte und Freund von Marx und Engels, 1846-1864, Berlin: Dietz. 
Schmidt, Walter with Gerhard Berger, Helmut Bleiber, Rolf Dlubek, Siegfried Schmidt and Rolf Weber 1973, Illustrierte Geschichte der deutschen Revolution 1848/49, Berlin: Dietz.

Siemann, Wolfram 1998 [1985], The German Revolution of 1848-49, Basingstoke: Palgrave Macmillan.

Sperber, Jonathan 1991, Rhineland Radicals, Princeton: Princeton University Press.

Sperber, Jonathan 2005, The European Revolutions, 1848-1851, Cambridge: Cambridge University Press.

Sperber, Jonathan 2013, Karl Marx: A Nineteenth Century Life, New York: Liveright.

Spoerer, Mark 2007, 'The Political Economy of Taxation in Nineteenth-Century Germany', in Taxation, State, and Civil Society in Germany and the United States from the 18th to the 2oth Century, edited by Alexander Nützenadel and Christoph Strupp, Baden-Baden: Nomos Verlagsgesellschaft.

Stedman Jones, Gareth 2016, Karl Marx: Greatness and Illusion, London: Allen Lane.

Strey, Joachim and Gerhard Winkler 1972, Marx und Engels 1848/49, Berlin: Dietz.

Sweezy, Paul 1942, The Theory of Capitalist Development, New York: Monthly Review Press.

Wagner, Adolph 1904, 'Zur Methodik der Statistik des Volkseinkommens und Volksvermögens - mit besonderen Berücksichtigung der Steuerstatistik', Zeitschrift des Königlichen Preußischen Statistischen Bureaus, 44, II: 41-122.

Wolff, Wilhelm 1886 [1849], Die Schlesische Milliarde, Hottingen-Zürich: Verlag der Volksbuchhandlung. 